\title{
27. MAGNETIC PROPERTIES OF BASALTS FROM ODP HOLE 648B ON THE MID-ATLANTIC RIDGE NEAR $23^{\circ} \mathbf{N}^{1}$
}

\author{
M. Mansour Bina ${ }^{2}$
}

\begin{abstract}
Seventeen samples from pillow or massive "zero age" fresh basalts from ODP Legs 106 and 109 were studied in order to examine their magnetic properties and oxidation degree. Thermomagnetic analyses of studied samples show Curie temperatures from $127^{\circ} \mathrm{C}$ to $220^{\circ} \mathrm{C}$ with reversible heating and cooling curves. Hysteresis parameters indicate the contribution of large Pseudo-Single Domain (PSD) grain of titanomagnetites with saturation magnetization between 0.4 and $0.7 \mathrm{emu} / \mathrm{g}$ which is almost twice that those of other recent mid-oceanic dredged basalts (e.g., FAMOUS and CYAMEX-RISE). The large grain sizes and higher magnetic mineral concentration may suggest a slower cooling of these basalts compared to those previously studied. Electron microprobe analyses of titanomagnetite grains combined with Curie point determinations give $\mathrm{z}=0.3$ for the degree of low temperature oxidation, which is close to the other values reported for low temperature oxidation of mid-oceanic ridge basalts.
\end{abstract}

\section{INTRODUCTION}

This paper reports on the magnetic properties, opaque microscopy, and electron microprobe analysis of 17 basalts samples from Site 648B of the ODP Legs 106 and 109. This site offers the possibility of investigation of fresh and young "zero age" basalts having a very low degree of alteration. Since older ocean floor basalts hold a reduced natural remanent magnetization (NRM) due to low temperature alteration, it is important to study the initial state of these rocks.

From $50.5 \mathrm{~m}$ of drilling, three lithological units of basalts could be identified: the upper unit $(30 \mathrm{~m})$ consists of pillows, the medium unit $(3 \mathrm{~m})$ of vesicular facies, and the lower part of massive flows.

In order to determine the size, composition, and concentration of the magnetic carriers of these rocks, we have studied the following aspects:

1. Intensity, stable inclination, and median demagnetizing field $\left(\mathrm{MDF}_{\mathrm{n}}\right)$ of NRM;

2. Magnetic initial susceptibility $(\chi)$ and Koenigsberger ratio $Q$;

3. Anhysteretic remanent magnetization (ARM) and its median demagnetizing field $\left(\mathrm{MDF}_{\mathrm{a}}\right)$;

4. Thermomagnetic behavior and Curie temperature $\left(\mathrm{T}_{\mathrm{c}}\right)$;

5. Thermal variation of initial susceptibility;

6. Hysteresis loop parameters:

7. Opaque mineral microscopy, for size determination of the magnetic minerals from thin polished sections of samples; and

8. Ulvospinel content and low temperature oxidation degree by combining electron microprobe analysis and thermomagnetic studies.

\section{EXPERIMENTAL PROCEDURE}

Magnetic remanence was measured with a JR4 spinner magnetometer and susceptibility with a Kappa-Bridge (both Czechoslovakianmade). Alternating field (AF) demagnetization to a maximum peak field of 2800 Oe were performed with a laboratory-built demagnetizer

\footnotetext{
${ }^{1}$ Detrick, R., Honnorez, J., Bryan, W. B., Juteau, T., et al., 1990. Proc. ODP, Init. Repts., 106/109: College Station, TX (Ocean Drilling Program).

${ }^{2}$ Laboratoire de Géomagnétisme du Parc St. Maur, Université Paris 6 et Centre National de la Recherche Scientifique.
}

(Le Goff, 1985). Hysteresis parameters were obtained using an automatic translating magnetometer (made at the laboratory) using fields up to $15 \mathrm{kOe}$. Thermal behavior was investigated either in strong field, on a few milligrams of rock under vacuum in a quartz capsule with a Satoris thermomagnetic balance at Université de Rennes, or under low field (thermal variation of susceptibility) using a laboratorymade translating inductometer with furnace (Bina, 1966).

\section{RESULTS}

The NRM intensity $\left(J_{n}\right)$ and viscosity index $(v)$ were obtained according to the Thellier and Thellier (1959) method. The viscosity index is usually a factor of NRM stability. For submarine basalts, low values of $v(1 \%-2 \%)$ are usually observed for fine magnetic grains in pillow basalts and rather high values for large grained doleritic basalts (Prévot et al., 1981; Smith, B., 1984). $v$ for our sample collection varies from $2 \%$ to $7 \%$ in the pillows and $7 \%-8 \%$ in massive basalts (Table 1). An inverse correlation between $v$ and $\mathrm{H}_{\mathrm{c}}$ is observed (Fig. 1). The intensity of NRM averages 101 (in $10^{-4} \mathrm{emu} / \mathrm{cm}^{3}$ ) with s.d. $=30$ and does not seem dependent on lithological type. Since NRM, as well as susceptibility, is dependent on the grain size, the chemical composition, and the percentage of magnetic mineral, the normalization of NRM and $\chi$ by its saturation magnetization $\left(J_{s}\right.$, which is grain size independent), would be more representative of the domain state. $\mathrm{J}_{\mathrm{n}} / \mathrm{J}_{\mathrm{s}}$ decreases and $\chi / J_{\mathrm{s}}$ increases slightly from pillow to massive basalts. The $\mathrm{Q}$ ratio $\left(\mathrm{J}_{\mathrm{n}} / \chi \times \mathrm{h}\right)$, calculated for $\mathrm{h}=0.4 \mathrm{Oe}$ (from IGRF data at the site) averages 22 with standard deviation $=$ 8 for the pillows and 8 for the massive flow. The median demagnetizing field for NRM $\left(M^{2} F_{n}\right)$, obtained for NRM free from VRM, averages 87 Oe (s.d. $=22$ ) and well reflects the coercivities of the samples. $\mathrm{MDF}_{\mathrm{n}}$ is almost four times smaller than those of the FAMOUS and CYAMEX-GEOMETEP pillow basalts (Prévot al., 1981; Smith, B., 1984).

Most of samples drilled between 10 and $20 \mathrm{~m}$ depth, gave negative inclinations. Hypotheses which can explain this phenomenon are discussed in the paleomagnetic section in this volume.

\section{ANHYSTERETIC REMANENT MAGNETIZATION (ARM) AND MDF}

Because of some similarities between the acquisition process of TRM and ARM, several studies have been carried out to compare the magnetic properties of these magnetizations 
Table 1. Magnetic remanent properties for Hole 648B; $v \%=$ viscosity index (see text); $\mathrm{J}_{\mathrm{n}}=\mathrm{NRM}$ intensity in $10^{-4} \mathrm{emu}^{\mathrm{c}} \mathrm{cm}^{3} ;$ Is $=$ stable inclination of NRM in degrees; $J_{s}=$ induced saturation magnetization (see Table 2 ); $\chi=$ susceptibility in $10^{-4} \mathrm{emu} / \mathrm{cm}^{3}$ Oe; $J_{a}=A R M$ intensity in $10^{-4} \mathrm{emu} /$ $\mathrm{cm}^{3} ; \mathrm{MDF}_{\mathrm{n}}, \mathrm{MDF}_{\mathrm{a}}=$ median demagnetizing field for $\mathrm{NRM}$ or $\mathrm{ARM}$.

\begin{tabular}{|c|c|c|c|c|c|c|c|c|c|c|c|c|c|c|}
\hline Sample & $\begin{array}{l}\text { Depth } \\
\text { (m) }\end{array}$ & $v \%$ & $\mathbf{J}_{\mathrm{n}}$ & $\mathbf{I}_{\mathrm{s}}$ & $\mathrm{MDF}_{\mathrm{n}}$ & $x$ & $\mathrm{~J}_{\mathbf{n}} / \mathrm{J}_{\mathrm{s}}$ & $x / \mathbf{J}_{\mathrm{s}}$ & $\mathrm{Q}$ & $\mathbf{J}_{\mathrm{a}}$ & $\mathrm{MDF}_{\mathrm{a}}$ & $\mathrm{J}_{\mathrm{a}} / \mathrm{J}_{\mathrm{n}}$ & $\mathrm{MDF}_{\mathrm{a}} / \mathrm{MDF}_{\mathrm{n}}$ & Comments \\
\hline 1R-1, 90-92 & 8.62 & 5 & 65 & 40.5 & 113 & 8.2 & 61.2 & 7.7 & 21 & 55 & 67 & 0.8 & 0.6 & pillow \\
\hline $1 \mathrm{R}-1,143-145$ & 9.90 & 3 & 133 & 33 & 50 & 9.3 & 132.4 & 9.3 & 36 & 75 & 60 & 0.6 & 1.2 & pillow \\
\hline $3 R-1,29-31$. & 16.49 & 2 & 118 & -48 & 113 & 10.5 & 79.4 & 7.1 & 30 & 74 & 68 & 0.6 & 0.6 & pillow \\
\hline $5 R-1,4-6$ & 15.48 & 3 & 88 & -57 & 70 & 12 & 64.4 & 8.8 & 18 & 44 & 56 & 0.5 & 0.8 & pillow \\
\hline $8 \mathrm{R}-1,48-50$ & 25.92 & 3 & 127 & 44 & 70 & 14 & 102.2 & 11.3 & 23 & 63 & 64 & 0.5 & 0.9 & pillow \\
\hline $8 R-1,65-67$ & 26.40 & 6 & 94 & 34 & 85 & 15.6 & 50.9 & 8.4 & 15 & 55 & 54 & 0.6 & 0.6 & pillow \\
\hline $9 \mathrm{R}-1,71-73$ & 31.47 & 4 & 79 & 62 & 56 & 13.2 & 56.1 & 9.4 & 15 & 48 & 85 & 0.6 & 1.5 & pillow \\
\hline $15 \mathrm{R}-1,4-6$ & 24.29 & - & 133 & 82 & 71 & 12.1 & 95.8 & 8.7 & 27 & 61 & 64 & 0.5 & 0.9 & pillow \\
\hline $15 \mathrm{R}-1,12-14$ & 24.86 & 3 & 103 & 54 & 106 & 8.7 & 85.2 & 7.2 & 29 & 79 & 109 & 0.8 & 1.0 & pillow \\
\hline $15 \mathrm{R}-1,58-60$ & 28.18 & 3 & 109 & -23 & 99 & 9.0 & 95.9 & 7.9 & 30 & 75 & 85 & 0.7 & 0.9 & pillow \\
\hline $15 \mathrm{R}-1,85-87$ & 30.12 & 5 & 94 & 75 & 99 & 11.5 & 72.6 & 8.9 & 20 & 72 & 79 & 0.8 & 0.8 & pillow \\
\hline $15 \mathrm{R}-1,92-94$ & 30.62 & 8 & 54 & 84 & - & 12.3 & 37.8 & 8.6 & 11 & 56 & 79 & 1.0 & - & pillow \\
\hline $15 \mathrm{R}-1,113-115$ & 32.14 & 7 & 82 & 75 & 92 & 17 & 41.4 & 8.6 & 12 & 60 & 56 & 0.7 & 0.6 & pillow \\
\hline $15 \mathrm{R}-1,135-137$ & 33.72 & 3 & 172 & 74 & 141 & 15.4 & 100.7 & 9.0 & 28 & 92 & 92 & 0.5 & 0.7 & pillow \\
\hline $16 \mathrm{R}-1,40-48$ & 33.90 & - & 109 & 44 & 67 & 23.2 & 70.7 & 15.0 & 12 & - & - & - & - & pillow \\
\hline $18 \mathrm{R}-1,28-30$ & 40.65 & 8 & 77 & 36 & 92 & 26.5 & 39.0 & 13.4 & 7 & 49 & 42 & 0.6 & 0.5 & massive \\
\hline $19 \mathrm{R}-1,15-17$ & 47.80 & 8 & 75 & 46 & 78 & 20.7 & 47.5 & 13.1 & 9 & 50 & 35 & 0.7 & 0.4 & massive \\
\hline
\end{tabular}

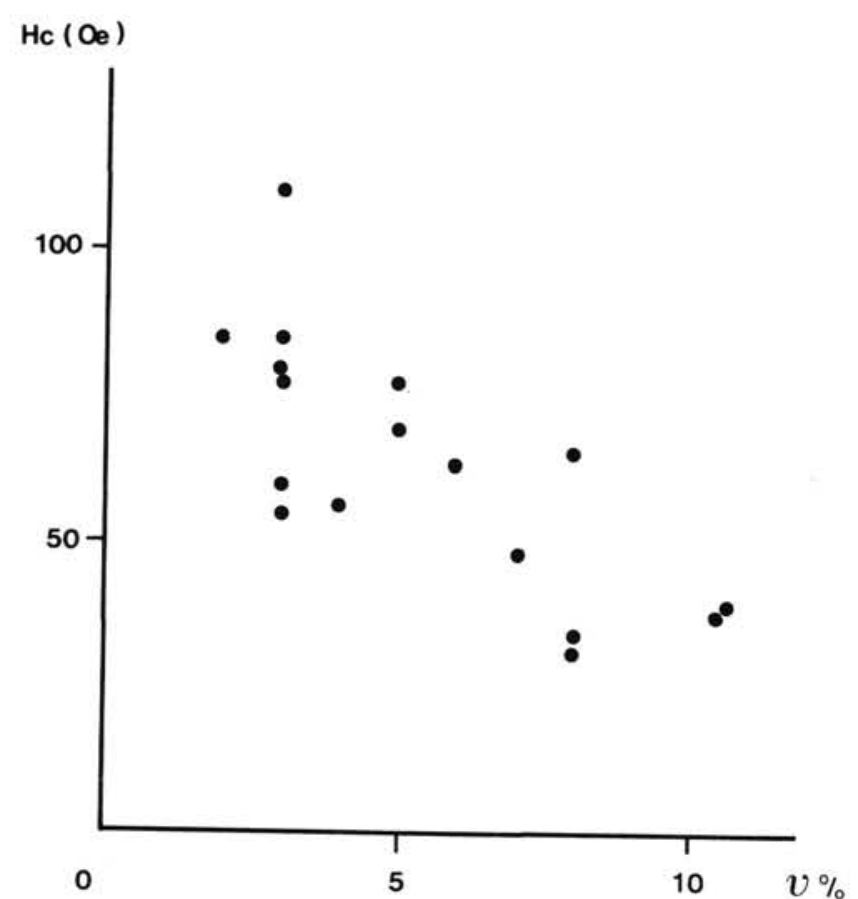

Figure 1. Variation of viscosity index, according to Thellier and Thellier's (1959) method, with coercive force.

(e.g., Rimbert, 1958; Levi and Merrill, 1976; Harstra, 1985). Néel (1955) has explained theoretically, for single-domain (SD) and multidomain (MD) grains, the ARM acquisition mechanism. Laboratory produced ARM has advantage over TRM in that it does not alter the mineralogy of the samples. For magnetite, ARM intensity, $J_{a}$, is usually found to be less than TRM (Levi and Merrill, 1976; Harstra, 1985). For oceanic basalts, values of $J_{a} / J_{n}>1$ were observed for Legs 82 and 83 (Smith and Banerjee, 1985a; 1985b); and $\mathrm{J}_{\mathrm{a}} / \mathrm{J}_{\mathrm{n}}$ mainly less than 1 for Legs 51, 52, 53 (Hamano et al., 1979). We have obtained $\mathrm{J}_{\mathrm{a}}$ in a field $\mathrm{h}=0.4$ Oe by stepwise increases of the $\mathrm{AF}$ intensity $\mathrm{H}$ from 50 to $2100 \mathrm{Oe}$. A line was then fitted to linear approach as $1 / \mathrm{H} \rightarrow 0$ for the ARM intensity curve to obtain saturation value of ARM. With this method an average value of $\mathrm{J}_{\mathrm{a}} / \mathrm{J}_{\mathrm{n}}$ of $0.6\left(\mathrm{~s} . \mathrm{d}\right.$. $=0.2$ ) was obtained. $\mathrm{MDF}_{\mathrm{a}}$ is also less than $\mathrm{MDF}_{\mathrm{n}}$ with average ratio $\mathrm{MDF}_{\mathrm{a}} / \mathrm{MDF}_{\mathrm{n}}=0.8$ (s.d. $=$ 0.3 ). A similar value has been observed for Leg 82 and 83 basalts (Smith and Banerjee, 1985a; 1985b) and values near unity for Leg 51 and 52 basalts (Hamano et al., 1979).

\section{HYSTERESIS LOOP PARAMETERS}

Hysteresis loop parameters characterize the intrinsic behavior of magnetic carriers in the samples and are useful to study the origin of NRM. These parameters were determined for all samples and are listed in Table 2. Saturation magnetization $\left(\mathrm{J}_{\mathrm{s}}\right)$, which is a parameter independent of grain size, allows the calculation of the amount of magnetic mineral content in the sample when its chemical composition and spontaneous magnetization are known. $\mathrm{J}_{\mathrm{s}}$ varies from 0.370 to $0.718(\mathrm{emu} / \mathrm{g})$, with a trend to increase with depth. Average $\mathrm{J}_{\mathrm{s}}$ for pillows $(0.518$ with s.d. $=0.112)$ is found to be stronger than for other mid-oceanic basalts, which suggests a higher magnetic mineral concentration: twice that found in the FAMOUS and CYAMEX-GEOMETEP dredged pillow basalts (Prévot et al., 1981; Smith, B., 1984). The higher magnetic mineral concentration of Site $648 \mathrm{~B}$ basalts may be explained by longer cooling time of these basalts, which generally increases both the proportion of magnetic mineral crystallization and the grain sizes (Marshall and Cox, 1971). However other parameters such as: the amount of iron and titanium present in the magma; low temperature oxidation; and various amount of minor elements possibly substituted for iron within the titanomagnetite structure (Ozdemir and O'Reilly, 1978) can also have effect on $\mathrm{J}_{\mathrm{s}}$ and other magnetic parameters. The strong inverse correlation between $\mathrm{J}_{\mathrm{s}}$ and $\mathrm{J}_{\mathrm{rs}} / \mathrm{J}_{\mathrm{s}}$ (taken as size parameter) can be seen in Figure 2. The same trend has been observed for Leg 53 pillow basalts (Hamano et al., 1979).

Remanent saturation magnetization $\left(\mathrm{J}_{\mathrm{rs}}\right)$ varies from 0.161 to $0.061(\mathrm{emu} / \mathrm{g})$, from pillow to massive basalts. $\mathrm{J}_{\mathrm{rs}}$ is a parameter depending on the composition, magnetic mineral content, and grain sizes. The ratio $\mathrm{J}_{\mathrm{rs}} / \mathrm{J}_{\mathrm{s}}$ is often used as a domain state diagnostic and does not depend on composition except through the number of easy axes of magnetization. The average value for the pillows is 0.23 (s.d. $=0.06$ ) and for massive units is 0.10 . Both pillow and massive basalts seem contain PSD titanomagnetite grains more or less close to PSD-MD threshold size. Microscopic observation of opaque minerals in thin polished section has revealed grain sizes mainly less than $10 \mu \mathrm{m}$ for pillows and 5-20 $\mu \mathrm{m}$, with size 
Table 2. Hysteresis loop parameters and Curie temperatures in Hole $648 B \mathrm{~J}_{s}, \mathrm{~J}_{\mathrm{rs}}=$ induced and remanent saturation magnetization in $\mathrm{emu} / \mathrm{g} ; \mathrm{H}_{\mathfrak{f}}, \mathrm{H}_{\mathrm{cr}}=$ coercive and remanent coercive forces in Oe; $\mathrm{kp}=$ paramagnetic susceptibility in $10^{-5} \mathrm{emu} / \mathrm{g} \mathrm{Oe} ; \mathrm{T}_{\mathrm{ci}}, \mathrm{T}_{\mathrm{ce}}=$ Curie temperature from inflection point or from extrapolation method (see text) in degrees Celsius.

\begin{tabular}{lccrrrrrrrr}
\hline \multicolumn{1}{c}{ Sample } & $\mathrm{J}_{\mathrm{s}}$ & $\mathrm{J}_{\mathrm{rs}}$ & $\mathrm{H}_{\mathrm{c}}$ & $\mathrm{H}_{\mathrm{cr}}$ & $\mathrm{J}_{\mathrm{rs}} / \mathrm{J}_{\mathrm{s}}$ & $\mathrm{H}_{\mathrm{cr}} / \mathrm{H}_{\mathrm{c}}$ & $\mathrm{kp}$ & $\mathrm{T}_{\mathrm{ci}}$ & $\mathrm{T}_{\mathrm{ce}}$ & Comments \\
\hline IR-1, 90-92 & 0.370 & 0.105 & 77 & 123 & 0.29 & 1.6 & 2.4 & 80 & 130 & pillow \\
1R-1, 143-145 & 0.350 & 0.107 & 79 & 107 & 0.31 & 1.3 & 2.4 & 80 & 127 & pillow \\
3R-1, 29-31 & 0.533 & 0.146 & 85 & 135 & 0.27 & 1.6 & 2.5 & 90 & 140 & pillow \\
5R-1, 4-6 & 0.483 & 0.091 & 60 & 107 & 0.19 & 1.8 & 1.7 & 90 & 150 & pillow \\
8R-1, 48-50 & 0.439 & 0.107 & 55 & 106 & 0.24 & 1.9 & 2.9 & 100 & 160 & pillow \\
8R-1, 65-67 & 0.662 & 0.097 & 63 & 129 & 0.15 & 2.1 & 2.1 & 150 & 210 & pillow \\
9R-1, 71-73 & 0.503 & 0.086 & 56 & 103 & 0.17 & 1.8 & 2.7 & 130 & 220 & pillow \\
15R-1, 4-6 & 0.489 & 0.096 & 56 & 97 & 0.20 & 1.7 & 2.4 & 100 & 155 & pillow \\
15R-1, 12-14 & 0.427 & 0.153 & 110 & 137 & 0.36 & 1.2 & 2.6 & 100 & 147 & pillow \\
15R-1, 58-60 & 0.388 & 0.110 & 78 & 127 & 0.28 & 1.6 & 2.0 & 90 & 153 & pillow \\
15R-1, 85-87 & 0.456 & 0.113 & 69 & 106 & 0.25 & 1.5 & 2.6 & 80 & 140 & pillow \\
15R-1, 92-94 & 0.519 & 0.103 & 65 & 117 & 0.20 & 1.8 & 2.6 & 140 & 205 & pillow \\
15R-1, 113-115 & 0.718 & 0.103 & 48 & 105 & 0.14 & 2.2 & 2.4 & 115 & 162 & pillow \\
15R-1, 135-137 & 0.667 & 0.161 & 85 & 146 & 0.24 & 1.7 & 2.7 & 140 & 220 & pillow \\
16R-1, 40-48 & 0.454 & 0.095 & 53 & 103 & 0.17 & 1.9 & 2.5 & 85 & 155 & pillow \\
18R-1, 28-30 & 0.672 & 0.065 & 34 & 88 & 0.10 & 2.6 & 2.2 & 110 & 170 & massive \\
19R-1, 15-17 & 0.588 & 0.061 & 31 & 70 & 0.10 & 2.2 & 2.1 & 90 & 150 & massive \\
\hline
\end{tabular}

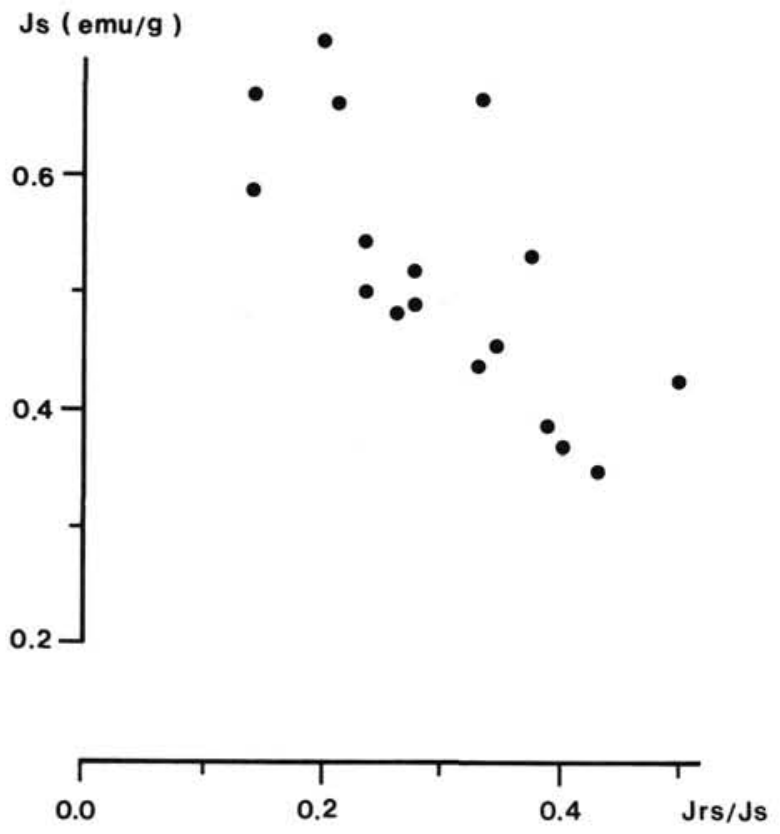

Figure 2. Variation of magnetic mineral concentration $\left(\mathrm{J}_{\mathrm{s}}\right)$ with grain size (presented here with $\mathrm{J}_{\mathrm{rs}} / \mathrm{J}_{\mathrm{s}}$ ) for studied samples.

sometimes larger than $50 \mu \mathrm{m}$, for massive basalt samples. Coercive force $\left(\mathrm{H}_{\mathrm{c}}\right)$ and remanent coercive force $\left(\mathrm{H}_{\mathrm{cr}}\right)$ were measured following saturation in $10 \mathrm{kOe}$ field. $\mathrm{H}_{\mathrm{c}}$ and $\mathrm{H}_{\mathrm{cr}}$ depend on composition and particularly on the size of the magnetic grains. $\mathrm{H}_{\mathrm{c}}$ (corrected for paramagnetism) varies clearly with lithological type between 31-34 Oe for massive basalts and 48-110 Oe for pillow samples. The ratio $\mathrm{H}_{\mathrm{cr}} / \mathrm{H}_{\mathrm{c}}$, also used as a domain structure diagnostic (e.g., Dunlop and Hale, 1977), ranges from 1.2 to 2.6 . However $\mathrm{H}_{\mathrm{cr}} / \mathrm{H}_{\mathrm{c}}$ is a less reliable parameter than $\mathbf{J}_{\mathrm{rs}} / \mathbf{J}_{\mathrm{s}}$ for size determination. Mixture of fine and coarse grains can produce a misleading ratio of $\mathrm{H}_{\mathrm{cr}} / \mathrm{H}_{\mathrm{c}}$ (Day et al., 1977). Some of the observed values, smaller than 2, which usually characterizes SD grains, may be related to this evidence.

Paramagnetic susceptibility (kp) was obtained from the hysteresis loop either by the slope of the hysteresis curve when ferrimagnetic saturation is thought to be reached and/or from a least squares fitting of the observed points on the approach to saturation and paramagnetism equation (Dunlop and Prévot, 1982). Well grouped values from 1.7 to 2.7 (in $10^{-5}$ $\mathrm{emu} / \mathrm{gOe}$ ) with an average of 2.4 are observed. $\mathrm{kp}$ is somewhat higher than values previously reported for oceanic basalts (Smith and Banerjee, 1985a; Smith, 1984).

\section{CURIE TEMPERATURE}

Curie temperature $\left(\mathrm{T}_{\mathrm{c}}\right)$ of titanomagnetite depends on the molecular fraction of ulvospinel (x), degree of low temperature oxidation $(\mathrm{z})$, and the minor elements substituted for iron in the titanomagnetite structure (Readman and O'Reilly, 1972; Ozdemir and O'Reilly, 1978). $\mathrm{z}$ is defined as the fraction of $\mathrm{Fe}^{2+}$ ions converted to $\mathrm{Fe}^{3+}$ during the maghemitization process (O'Reilly and Banerjee, 1966). For oceanic basalt titanomagnetites $(x=0.6)$, with low degree of oxidation $T_{c}$ is usually between $110^{\circ} \mathrm{C}$ and $150^{\circ} \mathrm{C}$ and the thermomagnetic curve is approximately reversible. However, irreversible thermomagnetic curves with a low calculated value of $z$ have been observed for some oceanic pillow basalts (Grommé et al., 1979; Prévot et al., 1981). Figure 3A shows two typical thermomagnetic curves from our sample collection. For some samples, $T_{c}$ was determined from thermal variation of initial susceptibility in low field (1-2 Oe) avoiding effect of paramagnetism. Because of low blocking temperatures, the Hopkinson peak appears at rather low temperatures (Fig. 3B).

In spite of having a clear physical definition, Curie temperature determination is empirical and rather ambiguous. To date, three methods have been used for determination of $\mathrm{T}_{\mathrm{c}}$ : (1) the inflection point of thermomagnetic curve (Bozorth, 1951; Schaeffer and Schwartz, 1970; Prévot et al., 1983); (2) more common is the intersection of the linear extrapolated thermomagnetic curve with the appropriate base line ( $\mathrm{T}$ axis if a single phase is present), (e.g., Grommé et al., 1969); (3) linear extrapolation of $\mathrm{J}_{\mathrm{s}}{ }^{2}$ vs. T near Curie point (Bozorth, 1951; Moskowitz, 1981). Differences of several tens of degrees are found using the different methods (Moskowitz, 1981; Prévot et al., 1983; Bina and Prévot, 1989). In Table 2, we have listed $\mathrm{T}_{c}$ using the first and second methods $\left(\mathrm{T}_{\mathrm{ci}}\right.$ and $\left.\mathrm{T}_{\mathrm{ce}}\right)$. As we have used the diagram of Grommé et al. (1979) for determination of oxidation degree $\mathrm{z}$, where the $\mathrm{T}_{\mathrm{c}}$ in the latter diagram is based on second method, $T_{c e}$ has been used for further calculations. 

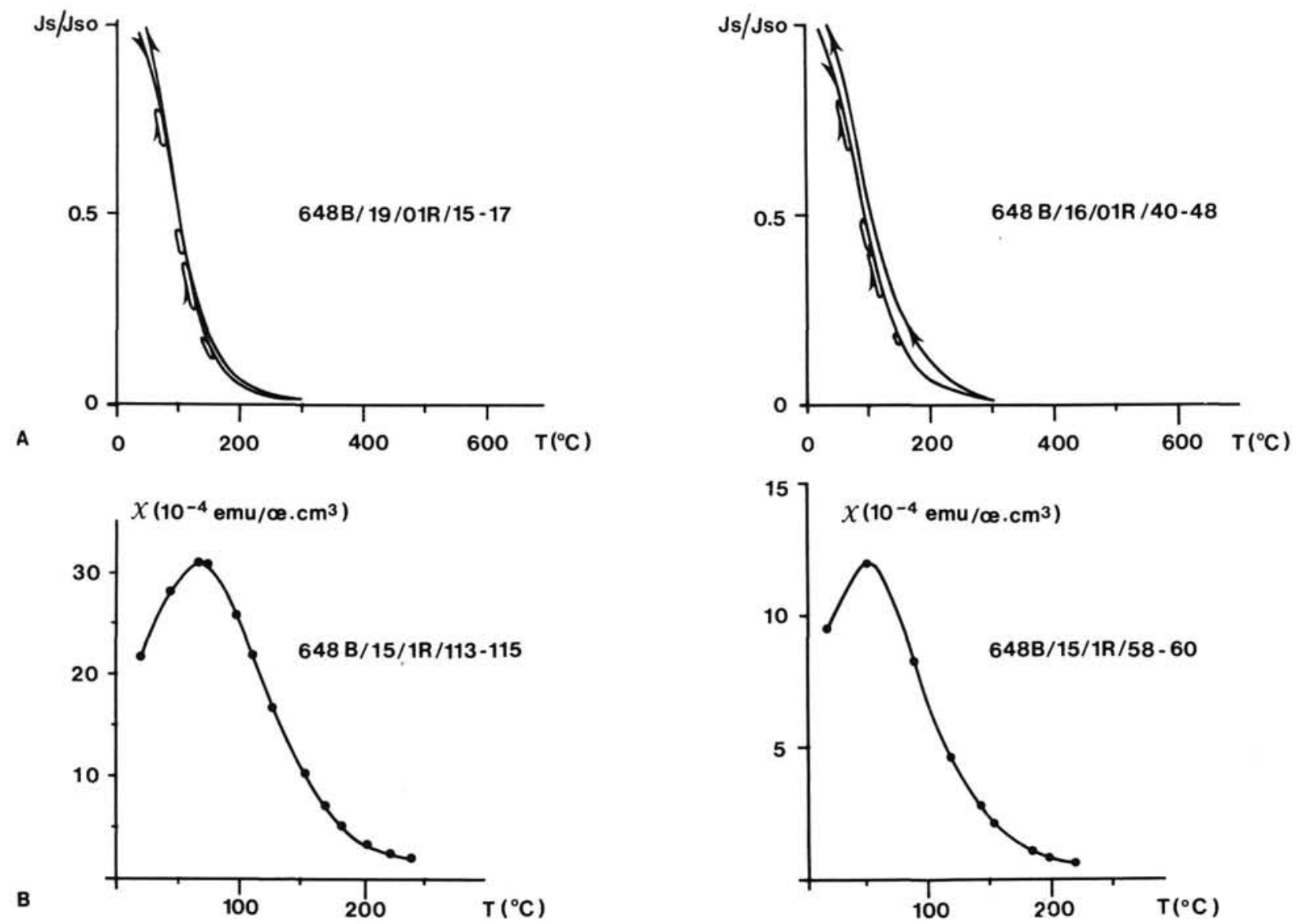

Figure 3. A. Two typical thermomagnetic curves from studied samples. Several short cooling tests can be seen on the heating curve for detection of temperature at which an eventual mineralogical evolution appears. B. Two typical curves of thermal variation of initial susceptibility $(\mathrm{h}=2 \mathrm{Oe})$.

Table 3. Electron microprobe analysis of basalts samples from Hole 648B; number of cations, $n$, for elements analyzed in titanomagnetite grains.

\begin{tabular}{lrcccccccccc}
\hline \multicolumn{1}{c}{ Sample } & N & Fe & Ti & Al & Mg & Mn & dTc & x & z & $x^{\prime}$ & $z^{\prime}$ \\
\hline IR-1, 90-92 & 10 & 2.198 & 0.602 & 0.121 & 0.054 & 0.024 & -65 & 0.60 & 0.2 & 0.64 & 0.2 \\
5R-1, 4-6 & 9 & 2.199 & 0.664 & 0.063 & 0.048 & 0.025 & -34 & 0.66 & 0.45 & 0.70 & 0.45 \\
9R-1, 71-73 & 10 & 2.243 & 0.600 & 0.069 & 0.066 & 0.022 & -37 & 0.60 & 0.5 & 0.63 & 0.5 \\
15R-1, 12-14 & 11 & 2.287 & 0.528 & 0.080 & 0.083 & 0.022 & -43 & 0.53 & 0.0 & 0.56 & 0.0 \\
15R-1, 58-60 & 9 & 2.230 & 0.621 & 0.065 & 0.058 & 0.026 & -35 & 0.62 & 0.4 & 0.65 & 0.4 \\
15R-1, 85-87 & 13 & 2.201 & 0.607 & 0.091 & 0.078 & 0.023 & -49 & 0.61 & 0.3 & 0.65 & 0.3 \\
16R-1, 40-48 & 10 & 2.265 & 0.597 & 0.078 & 0.039 & 0.020 & -42 & 0.60 & 0.3 & 0.63 & 0.3 \\
18R-1, 28-30 & 11 & 2.272 & 0.581 & 0.076 & 0.052 & 0.019 & -41 & 0.58 & 0.3 & 0.61 & 0.2 \\
19R-1, 15-17 & 12 & 2.223 & 0.643 & 0.071 & 0.043 & 0.021 & -38 & 0.64 & 0.4 & 0.67 & 0.4 \\
\hline
\end{tabular}

Note: $\mathrm{N}=$ number of analyses; $\mathrm{dT}_{\mathrm{c}}=$ Curie temperature changes by minor element substitutions in titanomagnetite structure, from Richards et al. (1973) and O'Donovan et al. (1977) data; $x, x^{\prime}=$ the $^{\prime}$ molecular content of ulvospinel in titanomagnetite, respectively, with and without minor element substitution assumption (see text), $\mathbf{z}, \mathbf{z}^{\prime}=$ degree of low temperature oxidation calculated for $\mathrm{x}$ and $\mathrm{x}^{\prime}$.

\section{DETERMINATION OF $z$}

Nine thin sections of pillow and massive basalts were analyzed with the CAMEBAX electron microprobe at the Université Paris 6 . When the electron spot was focused on a selected titanomagnetite grain, the very useful ORTEC SiLi detector allows a crude composition measurement before running a microprobe measurement. Local invisible silicate concentrations or grains other than titanomagnetite could be identified and avoided. For 9-13 analyses per thin section, the number of atoms ( $\mathrm{n}$ ) corresponding to a total of three cations for $4 \mathrm{O}^{2-}$ (unoxidized titanomagnetite structure) are calculated and listed in Table 3. Natural titanomagnetite always contains some minor elements such as $\mathrm{Al}, \mathrm{Mg}, \mathrm{Mn}, \ldots$ Assuming that these elements are substituted for iron, molecular content of ulvospinel $(\mathrm{x})$ is then $\mathrm{n}_{\mathrm{Ti}}$ (Prévot et al., 1981). If we assume that no substitution occurs and the measured minor elements, forming different minerals, are located in crystal deficiency (Grommé et al., 1979), then $\mathrm{x}^{\prime}=3 \mathrm{n}_{\mathrm{Ti}} /\left(\mathrm{n}_{\mathrm{Fe}}+\mathrm{n}_{\mathrm{Ti}}\right)$. The average values of $x$ and $x^{\prime}$ are 0.61 and 0.63 , close to other values reported for oceanic basalts (Grommé et al., 1979; Petersen et al., 1979; Prévot et al., 1981). From $\mathrm{x}$ and $\mathrm{T}_{\mathrm{c}}$ the low 
Table 4. Comparison between magnetic properties of Hole $648 \mathrm{~B}$ pillow basalts and other mid-oceanic ridge pillow basalts.

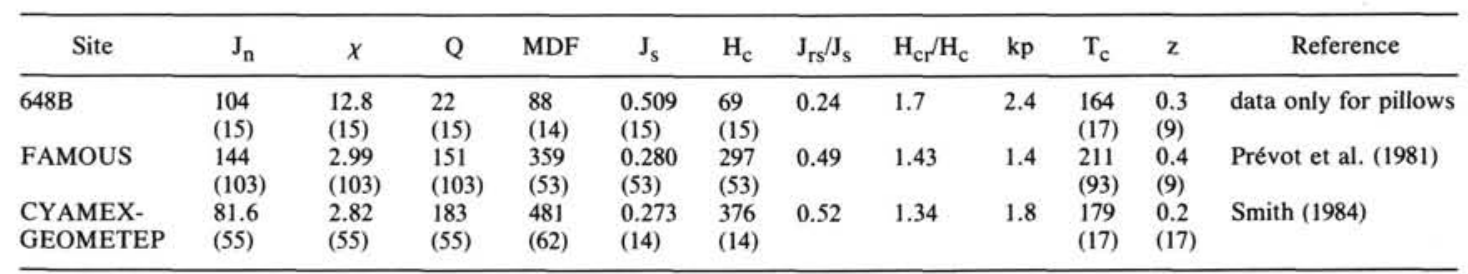

Note: Same definitions as Table 1 and 2. Value in parentheses is number of studied samples.

temperature oxidation index $\mathrm{z}$ was obtained from equal Curie temperature contours on the $1 / 3 \mathrm{Fe}_{2} \mathrm{TiO}_{4}, 1 / 3 \mathrm{Fe}_{3} \mathrm{O}_{4}, 1 / 2$ $\mathrm{Fe}_{2} \mathrm{O}_{3}, 1 / 3 \quad \mathrm{Fe}_{2} \mathrm{TiO}_{5}$ diagram (Grommé et al., 1979). This diagram was drawn from data from progressive oxidation, in the laboratory, of the cation deficient synthetic titanomagnetites. Richards et al. (1973) and O'Donovan and O'Reilly (1977) have observed that substitution of minor elements for iron within the titanomagnetite structure reduces the Curie temperature and changes the other intrinsic magnetic parameters of original titanomagnetite. The decrease of $T_{c}\left(d T_{c}\right)$ is then calculated for only the $\mathrm{Al}$ and $\mathrm{Mg}$ fractions. Since the amount of other cations is much lower, their effect can be neglected. Values obtained for $\mathrm{z}$ are listed in Table 3 and average for $\mathrm{z}=0.3$. However, some uncertainties remain concerning determination of the oxidation degree due essentially to:

1. Limitation of resolution and spotting dimension to about $10 \mu \mathrm{m}$ for microprobe analysis. Fine grains which are more sensitive to low temperature oxidation, cannot de analyzed.

2. Curie temperature determination, based on different empirical methods, can have also considerable effect on the determination of oxidation degree $z$.

In Table 4 , the oxidation degree $\mathrm{z}$ and some other magnetic parameters of our samples are compared with those of FAMOUS from Mid-Atlantic Ridge and also with results from CYAMEX-RISE and GEOMETEP, on the East Pacific Ridge. For almost the same degree of maghemitization the magnetic grain sizes and mineral content are largely different for Hole $648 \mathrm{~B}$ pillow basalts and the other mid-oceanic dredged pillow basalts.

\section{SUMMARY AND CONCLUSION}

1. Magnetic remanent properties of these basalts, NRM, $\chi$, $\mathrm{MDF}$, and Q ratio as well as hysteresis loop parameters reveal for pillow and massive units the contribution of PSD grains. Compared to other mid-oceanic ridge basalts, the larger grain size and magnetic oxide content seem to be essentially due to slower cooling rate of these basalts. However this latter suggestion needs to be supported by the petrological factors.

2. Curie temperatures averaging $164^{\circ} \mathrm{C}$ and reversibility of the thermomagnetic curves are qualitative assessments of a low degree of maghemitization.

3. Average values of oxidation degree is $z=0.3$ for these "zero age" fresh basalts. This suggests that the process of maghemitization may begin during initial cooling of the magma when oxidation is favored by ambient temperature; then, oxidation proceeds at a slower rate (Prévot et al., 1983).

\section{ACKNOWLEDGMENTS}

I would like to thank all the shipboard and shore-based colleagues who contributed to the success of Legs 106/109. I am particularly indebted to M. Prévot for suggestions and critical reading of manuscript, to Mme. D. Veld for help with the thin section preparation and microprobe analyses, and to R. Enkin for discussions and English clarification of the text. The results presented here would not be available without the technical aid of M. Le Goff. This research was supported by ODP France.

\section{REFERENCES}

Bina, M. M., 1966. Contribution l'étude de l'aimantation thermo rémanente porte par des roches, des terres cuites et des mineraux synthétiques. [Ph.D. dissert.] Univ. Paris.

Bina, M. M., and Prévot, M., 1989. Thermomagnetic investigations of titanomagnetite grain size in submarine basalts: evidence for differential maghemitization. Phys. Earth Planet. Int., 54:169-179.

Bozorth, R. M., 1951. Ferromagnetism. New York (Van Nostrand).

Day, R., Fuller, M. D., and Schmidth, V. A., 1977. Hysteresis properties of titanomagnetites: Grain size and compositional dependence. Phys. Earth Planet. Int., 13:260-267

Dunlop, D. J., and Hale, C. J., 1977. Simulation of long term changes in the magnetic signal of the oceanic crust. Can. J. Earth Sci., 14:716-744.

Dunlop, D. J., and Prévot, M., 1982. Magnetic properties and opaque mineralogy of drilled submarine intrusive rocks. Geophys. J. R. Astr. Soc. 69:763-802.

Grommé, C. S., Wright, T. L., and Peck, D. L., 1969. Magnetic properties and oxidation of iron-titanium oxide minerals in Alae and Makaopuhi lava lakes, Hawaii. J. Geophys. Res., 74:5277-5293.

Grommé, C. S., Mankinen, E. A., Marshall, M., and Coe, R. S., 1979. Geomagnetic paleointensities by the Thelliers' method from submarine pillow basalts: effects of sea floor weathering. $J$. Geophys. Res., 84:3553-3575.

Hamano, Y., Nishitani, T. and Kono, M., 1979. Magnetic properties of basalts samples from Deep Sea Drilling Project Holes 417D and 418A. In Donnelly, T., Francheteau, J., Bryan, W., Robinson, P., Flower, M., and Salisbury, M., Init. Repts. DSDP, 51, 52, 53 Pt 2: Washington (U.S. Govt. Printing Office), 1391-1405.

Harstra, R. L., 1985. TRM, ARM and Isr of two natural magnetites of MD and PSD grain sizes. Geophys. J.R. Astr. Soc., 75:719-737.

Le Goff, M., 1985. Description d'un appareil désaimantater par champs alternatifs; limination de l'aimantation rémanente anhysterétique parasite. Can. J. Earth Sci., 22:1740-1747.

Levi, S., and Merrill, R., 1976. A comparison of ARM and TRM magnetite. Earth Planet. Sci. Lett., 32:171-184.

Marshall, M. and Cox, A., 1971. Magnetism of pillow basalts and their petrology. Geol. Soc. America Bull., 82:537-552.

Moskowitz, B. M., 1981. Methods of estimating Curie temperatures of titanomagnetites from experimental $\mathrm{J}_{\mathrm{s}}-\mathrm{T}$ data. Earth Planet. Sci. Lett., 53:84-88.

Néel, L., 1955. Some theoretical aspects of rock magnetism. Phil. Mag., 4:191-242.

O'Donovan, J. B. and O'Reilly, W., 1977. The preparation, characterization and magnetic properties of synthetic analogues of some carriers of paleomagnetic record. J. Geomag. Geoelectr., 29:331-344.

O'Reilly, W., and Banerjee, S. K., 1966. Oxidation of titanomagnetites and self-reversal. Nature, 211:26-28.

Ozdemir, O., and O'Reilly, W., 1978. Magnetic properties of monodomain aluminium-substituted titanomagnetite. Phys. Earth Planet. Int., 16:190-195.

Petersen, N., Zisenach, P., and Bleil, U., 1979. Low temperature alteration of magnetic minerals in oceanic basalts. In Deep Drilling Results in the Atlantic Ocean: Ocean Crust. M. Ewing ser. 2, A.G.U., Washington, 169-209. 
Prévot, M., Lecaille, A. and Mankinen, E. A., 1981. Magnetic effect of maghemitization of oceanic crust. J. Geophys. Res. 86:4009-4020.

Prévot, M., Mankinen, E. A., Grommé, S. and Lecaille, A., 1983. High paleointensities of geomagnetic field from thermomagnetic experiments on the Rift Valley pillow basalts from mid-Atlantic Ridge near $36.8^{\circ} \mathrm{N}$. J. Geophys. Res., 88:2316-2326.

Readman, P. and O'Reilly, W., 1972. Magnetic properties of oxidized (cation deficient) titanomagnetites $(\mathrm{Fe}, \mathrm{Ti},)_{3} \mathrm{O}_{4}, J$. Geomag. Geoelect., 24:69-90.

Richards, J.C.W., O'Donovan, J. B., Hauptman, Z., O'Reilly, W., and Creer, K. M., 1973. Magnetic study of titanomagnetite substituted by magnesium and aluminium. Phys. Earth Planet. Int., 7:437-444.

Rimbert, F., 1958. Contribution l'étude de l'action de champs alternatifs sur les aimantations rémanentes des roches. Applications géophysiques. [Ph.D. dissert.] Univ. Paris.

Smith, B., 1984. Propérités magnétiques de roches basaltiques provenant de la couche 2 de la croute océanique; effets du degrée de cristallisation et de degrée d'alteration basse temperature. [Ph.D. dissert.] Univ. Paris 6.
Schaeffer, R. M., and Schwartz, E. J., 1970. The Mid-Atlantic Ridge near $45^{\circ} \mathrm{N}$ IX. Thermomagnetics of dredged samples of igneous rocks. Can. J. Earth Sci., 7:268-273.

Smith, G. M., and Banerjee, S. K., 1985a. Magnetic properties of basalts from the central North Atlantic Ocean. In Bougault, H., Cande, S. C., and Brannon, J. C. et al. Init. Repts. DSDP 82, Washington (U.S. Govt. Printing Office), 377-383. 1985b. Magnetic properties of basalts from Deep Sea Drilling Project Leg 83: The origin of remanence and its relation to tectonic and chemical evolution. In Andreson, R. N., Honnorez, J., Adamson, A. C., et al., Init. Repts. DSDP, 83: Washington (U.S. Govt. Printing Office), 369-375.

Thellier, E., and Thellier, O., 1959. Sur l'intensité du champ magnétique terrestre dans le pass historique et géologique. Ann. Géophys., 15:285-376.

Date of initial receipt: 21 January 1988

Date of acceptance: 19 December 1988

Ms 106/109B-160 